Jpn. J. Human Genet. 30, 31-34, 1985

\title{
CONGENITAL LYMPHEDEMA IN TWO SIBLINGS
}

\author{
Tadashi KAJII and Masato TsuKaHARA \\ Department of Pediatrics, Yamaguchi University School of Medicine, \\ Ube, Yamaguchi 755, Japan
}

Summary Two siblings, a two-year-old boy and a one-month-old girl, both showed congenital lymphedema of the feet. The parents were healthy and apparently unrelated, but both were born on Mishima, an island with a population of 1,500 , located in the Sea of Japan. The occurrence of lymphedema in these two siblings suggests autosomal recessive inheritance.

\section{INTRODUCTION}

There have been 14 separate syndromes in which hereditary lymphedema has been an important feature (McKusick, 1983; Kääriäinen, 1984). Most of these syndromes are autosomal dominant conditions. Lymphedema and cholestasis is an autosomal recessive condition that has been found in Norwegian kindreds (Aagenaes, 1974). The disease can be readily distinguished by recurrent cholestasis from other hereditary lymphedemas. Here we reveal a case of a brother and sister, both with lymphedema in legs since birth, suggesting the autosomal recessive case.

\section{CASE REPORTS}

Patient 1 (No. 811223), a two-year-old boy, had nonpitting edema of the feet since birth. He was born to a 24-year-old mother and a 25 -year-old father, who were considered healthy. The parents were apparently unrelated, but both were born on Mishima, an island with a population of 1,500 situated in the Sea of Japan, 44 $\mathrm{km}$ north of the northern coast of Yamaguchi Prefecture. The consanguinity rate among the residents on the island is high. Thus, the possibility of the parents being related in the distant past cannot be ruled out. The swelling of the feet of the boy slowly progressed. When seen at age two, both feet and the lower half of the left leg were affected (Fig. 1a). The boy was alert. His nipples were retracted, but he had no other malformations. In particular, he did not have yellow nails nor distichiasis. His serum total protein level was $6.4 \mathrm{~g} / \mathrm{dl}$.

Patient 2 (No. 811221), a one-month-old sister of Patient 1, showed lymphedema 

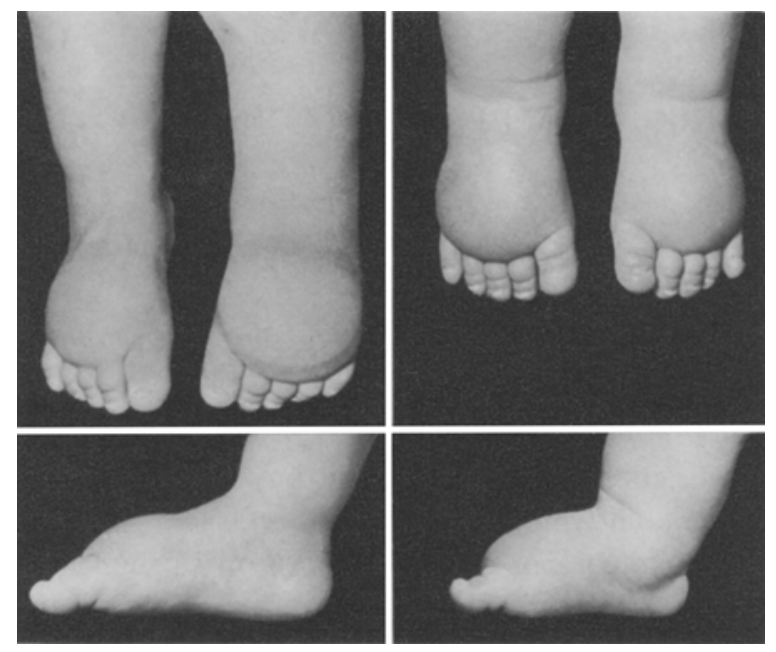

Fig. 1. Left: Patient 1 at age 2 years. Right: Patient 2 at age one month.

of the feet since birth (Fig. 1b). She was considered normal in other aspects.

G-banded chromosomes in cultured PB lymphocytes were normal in both patients.

\section{DISCUSSION}

The brother and sister we have described both have had lymphedema of the lower extremities since birth, while the parents show no past history of lymphedema. Thus, the condition in the siblings was most likely inherited as an autosomal recessive. Multifactorial inheritance cannot be ruled out, but is less likely, in view of the fact that the severity of the condition was similar between the siblings. Autosomal dominant inheritance with incomplete penetrance is unlikely because of the absence of the condition in at least two preceding generations in the pedigree.

As mentioned earlier, we are aware of 14 hereditary lymphedema syndromes (Table 1). There may be overlapping between them, as suggested by Kääriäinen (1984). Most of these syndromes are autosomal dominant conditions and can be identified by their respective additional features. Our siblings did not have yellow dystrophic nails, distichiasis or ptosis. Neither did they suffer from pleural effusion, diarrhea, growth failure, pulmonary hypertension, or neonatal cholestasis. Milroy's disease resembles the condition in the siblings we have described, since lymphedema is present at birth and no additional clinical features are perceived in both cases. The disease, however, is inherited in an autosomal dominant fashion. Hereditary recurrent cholestasis with lymphedema (Aagenaes, 1974) is an autosomal recessive condition, but it is characterized by neonatal intrahepatic cholestasis with jaundice. Congenital lymphedema with distichiasis and progressive weakness of the legs due 
Table 1. Hereditary lymphedema syndromes (modified from Holmes et al., 1978; Miller and Motulsky, 1978; and Kääriäinen, 1984)

\begin{tabular}{|c|c|c|c|c|}
\hline Type & $\begin{array}{c}\text { McKusick's } \\
\text { Catalogue } \\
\text { No.a. }\end{array}$ & $\begin{array}{l}\text { Inherit- } \\
\text { ance }\end{array}$ & $\begin{array}{l}\text { Age at onset } \\
\text { of } \mathbf{L}\end{array}$ & $\begin{array}{l}\text { Associated clinical } \\
\text { features }^{b}\end{array}$ \\
\hline Milroy's disease & 15310 & AD & At birth & $\begin{array}{l}\text { Pleural effusion, } \\
\text { chylous ascites }\end{array}$ \\
\hline Meige's disease & 15320 & $\mathrm{AD}$ & Puberty & \\
\hline $\mathrm{L}+$ intestinal lymphangiectasia & - & $\mathrm{AD}$ & Infancy & Diarrhea, growth failure \\
\hline$L+$ yellow nails & 15330 & $\mathrm{AD}$ & Adultfood & Recurrent pleural effusion \\
\hline $\mathrm{L}+$ distichiasis & 15340 & $\mathrm{AD}$ & $\begin{array}{l}\text { Puberty or } \\
\text { later }\end{array}$ & $\begin{array}{l}\text { Ectropion of lower lid, } \\
\text { spinal a nomalies }\end{array}$ \\
\hline $\mathrm{L}$-recurrent lymphangitis & - & $\mathrm{AD}$ & $\begin{array}{l}\text { Childhood } \\
\text { or puberty }\end{array}$ & \\
\hline $\mathrm{L}+$ cerebrovascular anomaly & 15290 & $\mathrm{AD}$ & $\begin{array}{l}\text { Puberty or } \\
\text { later }\end{array}$ & Pulmonary hypertension \\
\hline $\mathrm{L}+$ ptosis & 15300 & $\mathrm{AD}$ & Puberty & \\
\hline $\begin{array}{l}\mathrm{L}+\text { distichiasis, yellow nails } \\
\text { recurrent lymphangitis }\end{array}$ & - & AD & Puberty & \\
\hline Noonan syndrome & 16395 & AD & Puberty & $\begin{array}{l}\text { Short stature, mental defici- } \\
\text { ency, facial dysmorphia, } \\
\text { webbed neck, pulmonary } \\
\text { stenosis, septal defects }\end{array}$ \\
\hline Chylous ascites & 20830 & AR & At birth & Swelling of entire body \\
\hline $\mathbf{L}+$ recurrent cholestasis & 21490 & AR & $\begin{array}{l}\text { At birth or } \\
\text { childhood }\end{array}$ & $\begin{array}{l}\text { Recurrent cholestatic } \\
\text { jaundice described in } \\
\text { Norwegian families }\end{array}$ \\
\hline $\begin{array}{l}\mathrm{L}+\text { distichiasis, spinal extradural } \\
\text { cyst }\end{array}$ & 27110 & AR & At birth & $\begin{array}{l}\text { Progressive weakness in the } \\
\text { legs }\end{array}$ \\
\hline Turner syndrome & - & $45, \mathrm{X}$ & At birth & $\begin{array}{l}\text { Short stature, webbed neck, } \\
\text { coarctation of aorta }\end{array}$ \\
\hline
\end{tabular}

a McKusick, V.A., 1983. ' Not all clinical features are present in each case of a given syndrome. $\mathrm{L}$, lymphedema; AD, autosomal dominant; AR, autosomal recessive.

to a spinal extradural cyst is also an autosomal recessive condition (Chynn, 1967). The disease was described in a black brother and sister, ages 12 and 10, respectively, at the time of diagnosis. The disease in the siblings we have described seems different from this condition as distichiasis was absent in both siblings. Thus, our patients seem to represent a hitherto undescribed syndrome with congenita] lymphedema, most likely inherited in an autosomal recessive fashion.

\section{REFERENCES}

Aagenaes, $\Phi .1974$. Hereditary recurrent cholestasis with lymphedema. Two new families. Acta Paediatr. Scand. 63: 465-471.

Chynn, K.-Y. 1967. Congenital spinal extradural cyst in two siblings. Am. J. Roentgen. 101: 204 215. 
Holmes, L.B., Fieids, J.P., and Zabriskie, J.B. 1978. Hereditary late-onset lymphedema. Pediatrics 61: $575-579$.

Kääriäinen, H. 1984. Hereditary lymphedema: a new combination of symptoms not fitting into present classifications. Clin. Genet. 26: 254-256.

McKusick, V.A. 1983. Mendelian Inheritance in Man. 6th Ed. Johns Hopkins Univ. Press, Baltimore.

Miller, M. and Motulsky, A.C. 1978. Noonan syndrome in an adult family presenting with chronic lymphedema. Am. J. Med. 65: 379-383. 